\title{
CORRIGENDUM
}

Genes \& Development 30: 2657-2662 (2016)

\section{Corrigendum: CTCF-mediated topological boundaries during development foster appropriate gene regulation}

Varun Narendra, Milia Bulajić, Job Dekker, Esteban O. Mazzoni, and Danny Reinberg

In the above-mentioned article, the funding source CA-199652 to Danny Reinberg was missing from Acknowledgments. The last sentence of Acknowledgements has been corrected online to read as follows: "This work was supported by the Howard Hughes Medical Institute and grants from the National Institutes of Health (GM-64844 and CA-199652 to D.R., T32 GM007238 to V.N., HG003143 to J.D., and R01HD079682 to E.O.M.)." The authors apologize for this oversight.

doi: $10.1101 / \operatorname{gad} .306829 .117$ 


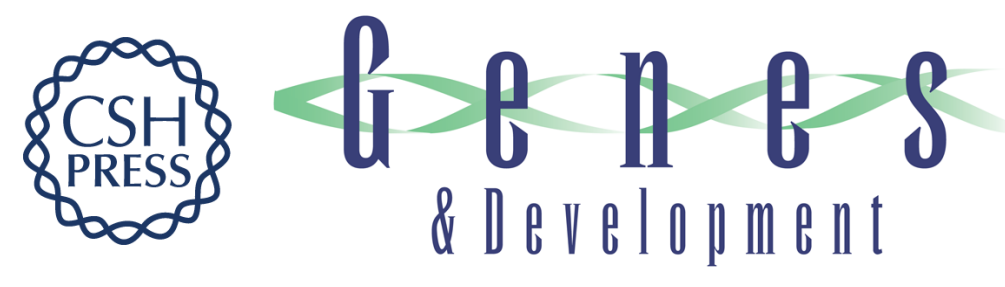

\section{Corrigendum: CTCF-mediated topological boundaries during development foster appropriate gene regulation}

Varun Narendra, Milia Bulajic, Job Dekker, et al.

Genes Dev. 2017, 31:

Access the most recent version at doi:10.1101/gad.306829.117

\section{Related Content \\ CTCF-mediated topological boundaries during development foster appropriate gene regulation \\ Varun Narendra, Milica Bulajic, Job Dekker, et al. \\ Genes Dev. December , 2016 30: 2657-2662 \\ License \\ Email Alerting Receive free email alerts when new articles cite this article - sign up in the box at the top Service right corner of the article or click here.}

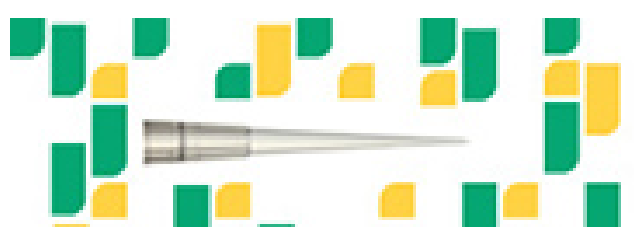

